\title{
TANGGUNG JAWAB DAN PERAN ORANG TUA DALAM PENDIDIKAN SHALAT BAGI ANAK USIA DINI
}

\author{
Mahmudin \\ Dosen, Sekolah Tinggi Ilmu Alquran (STIQ) Amuntai, Kalimantan \\ Selatan
}

\begin{abstract}
Abstrak
Anak adalah amanat yang dititipkan oleh Allah kepada orang tua, sebagai orang tua berkewajiban dan mempunyai tanggung jawab yang sangat besar dalam mendidik, sehingga kelak dapat menjadi anak-anak yang mempunyai akhlak terpuji dan taat melaksanakan segala perintah dan menjauhi segala larangan, diantara kewajiban orang tua terhadap anak adalah dalam hal pengajaran shalat. Islam mengajarkan kepada ummatnya untuk memiliki sifat tanggung jawab yang telah ditegaskan dalam alQuran serta contoh teladan dari Rasulullah saw. Sebagai ummat islam kita berkewajiban melaksanakan apa yang diperintahkan oleh Allah dalam alQuran dan Rasulullah dalam sunnahnya. Tanggung jawab disini berkaitan dengan tanggung jawab manusia terhadap Allah, keluarga, dan masyarakat. Diantara tanggung jawab yang sangat besar bagi orang tua adalah dalam hal pendidikan shalat bagi anak usia dini. Dengan dimulainya mengerjakan shalat pada usia ini, maka anak mulai ditanamkan untuk menghargai waktu agar tidak merugi. Karena manusia dapat terpuruk ke dalam lembah kejahatan dan kerugian.
\end{abstract}

Kata Kunci: tanggung jawab, pendidikan, shalat, usia dini

\section{A. Pendahuluan}

Islam mengajarkan kepada ummatnya untuk memiliki sifat tanggung jawab yang telah ditegaskan dalam al-Quran serta contoh teladan dari Rasulullah saw. Sebagai ummat islam kita berkewajiban melaksanakan apa yang diperintahkan oleh Allah dalam al-Quran dan Rasulullah dalam sunnahnya. Tanggung jawab disini berkaitan dengan tanggung jawab manusia terhadap Allah, keluarga, dan masyarakat. Diantara tanggung jawab yang sangat besar bagi orang tua adalah dalam hal pendidikan shalat bagi anak usia dini.

Pendidikan adalah upaya sadar dari orang tua atau lembaga pendidikan untuk mengenalkan anak (peserta) didik kepada Allah, Tuhan yang telah 
Mahmudin: Tanggung Jawab dan Peran Orang Tua dalam Pendidikan Shalat Bagi Anak Usia Dini

menciptakannya, agar dia bisa menggunakan seluruh potensi yang telah Allah anugerahkan untuk beribadah kepada-Nya dalam rangka mensyukuri nikmatNya, dan untuk berbuat baik kepada sesama dengan selalu mengutamakan akhlak. $^{1}$

Pendidikan terhadap anak dimulai sejak anak lahir kedunia. Pada hakikatnya anak yang baru saja lahir sudah berkewajiban menuntut ilmu, tetapi anak yang baru lahir belum bisa mencari ilmu sendiri. Sebagaimana yang dikatakan dari penelitian bahwa anak adalah generasi masa depan, dipundak anaklah rancang bangun masa depan bangsa, negara dan agama (Islam), dibebankan $^{2}$ Maka adalah kewajiban orang tua yang mengarahkan anakanaknya untuk menjadi anak-anak yang shaleh dan shalehah, karena orang tua merupakan pendidik utama dan pertama bagi anak-anak mereka. Dari orang tua lah anak-anak pertama kali menerima pendidikan. Hal ini menunjukkan betapa besar tanggung jawab orang tua dalam pendidikan anak-anaknya. Apalagi kalau kita melihat bahwa tujuan pendidikan dalam Islam ialah terbentuknya insan kamil dengan pola taqwa. ${ }^{3}$

Anak shaleh memang menjadi dambaan setiap keluarganya, tetapi dalam meraihnya, tidak segampang yang diharapkan harus melalui proses panjang, dibutuhkan ketekunan dan kejelian dalam mendidik, dan kesiapan artinya orang tua dalam mengantarkannya menjadi insan shaleh, kesiapan artinya orang tua harus memiliki pengetahuan cukup tentang cara mendidik anak serta mengetahui masa perkembangannya, sehingga dalam mengukir nilai moral dalam jiwanya bisa sesuai lagi tepat dari kebutuhannya. ${ }^{4}$

\footnotetext{
${ }^{1}$ Amka Abdul Aziz, Hati Pusat Pendidikan Karakter (Klaten : Cempaka Putih, 2012), h.44-45.

2 Agus Setiawan, Metode Pendidikan Islam Masa Kini dalam Keluarga Perspektif Abdullah Nashih Ulwan, EDUCASIA, Vol. 1 No. 2, 2016, h.138.

${ }^{3}$ Zakiah Daradjat, Ilmu Pendidikan Islam, Cet. I (Jakarta: Bumi Aksara, 1996), h. 36.

${ }^{4}$ Aba Firdaus al-Halawani, Melahirkan Anak Shaleh (Yogyakarta: Mitra Pustaka, 2003), h. 5.
} 
Mahmudin: Tanggung Jawab dan Peran Orang Tua dalam Pendidikan Shalat Bagi Anak Usia Dini

Anak adalah amanat yang dititipkan oleh Allah kepada orang tua, sebagai orang tua berkewajiban dan mempunyai tanggung jawab yang sangat besar dalam mendidik, sehingga kelak dapat menjadi anak-anak yang mempunyai akhlak terpuji dan taat melaksanakan segala perintah dan menjauhi segala larangan, diantara kewajiban orang tua terhadap anak adalah dalam hal pengajaran shalat. Anak adalah generasi mendatang yang mewarnai masa kini dan diharapkan dapat membawa kemajuan dimasa mendatang.Anak juga merupakan ujian bagi setiap orangtua sebagaimana disebutkan dalam Al-Qur'an surah al-Anfal ayat 28 yang berbunyi :

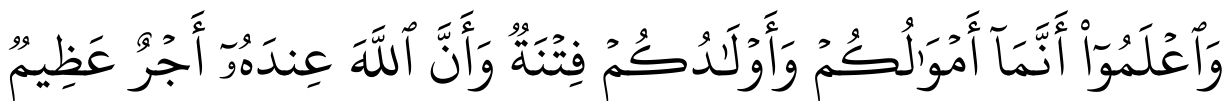

Artinya :"Dan ketahuilah bahwa hartamu dan anak-anakmu itu hanyalah sebagai cobaan dan sesungguhnya disisi Allahlah pahala yang besar.” (QS.alAnfal ayat 28).

Dengan dimulainya mengerjakan shalat pada usia ini, maka anak mulai ditanamkan untuk menghargai waktu agar tidak merugi. Karena manusia dapat terpuruk ke dalam lembah kejahatan dan kerugian. Keduanya dapat dihindari apabila manusia mau menghargai waktu. Sesuai dengan firman Allah dalam AlQur'an:

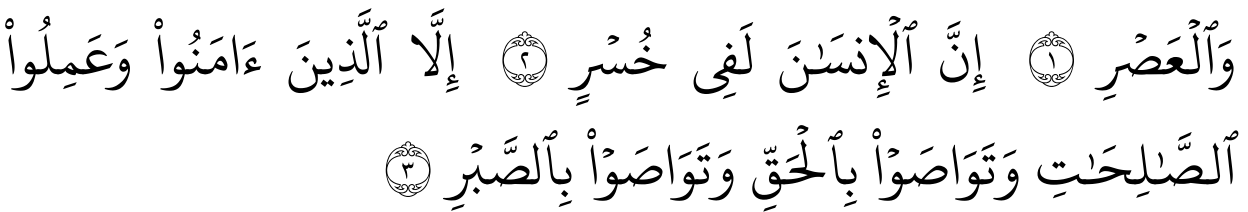

Artinya"Demi masa, sesungguhnya manusia itu benar-benar berada dalam kerugian, kecuali orang-orang yang beriman dan mengerjakan amal shaleh dan saling menasihati supaya menaati kesabaran, dan saling menasihati supaya menetapi kebenaran”. (QS.Al-“Ashr:1-3).

Kebiasaan tersebut di atas sangat baik untuk ditanamkan kepada anakanak sebagai perilaku disiplin, hingga anak mencapai usia tujuh tahun, yakni 
Mahmudin: Tanggung Jawab dan Peran Orang Tua dalam Pendidikan Shalat Bagi Anak Usia Dini

ketika anak mulai mengejakan shalat. Dalam hubungan ini hadits Rasulullah saw. Menerangkan :

"suruhlah anak-anakmu mengerjakan shalat pada usia tujuh tahun dan pukullah mereka agar mau mengerjakan shalat pada umur sepuluh tahun”. (HR.Ahmad, Abu Daud dan Al-Hakim dari ibnu “Amr ra.)

Selain menghargai waktu, dengan megerjakan shalat anak-anak akan terbiasa dengan sikap disiplin sebagai berikut :

a. Bersih, yaitu bersuci dengan wudlu, membersihkan muka, tangan dan kaki, membersihkan diri dari hadas kecil dan hadas besar dengan air yang suci dan mensucikan, termasuk kebersihan pakaian, tempat dan alat-alat shalat.

b. Belajar menutup aurat.

c. Menghormati pimpinan atau iman.

d. Mengingat Allah yang dapat memberikan ketenangan pikiran yang sangat berguna terutama bagi remaja.

e. Selanjutnya dengan mengerjakan shalat mendidik remaja menghadapi masa puber yang sangat berbahaya karena shalat yang sesungguhnya mencegah orang berbuat kejahatan dan larangan (yang mungkar).Firman Allah dalam Al-Qur'an, yang artinya :

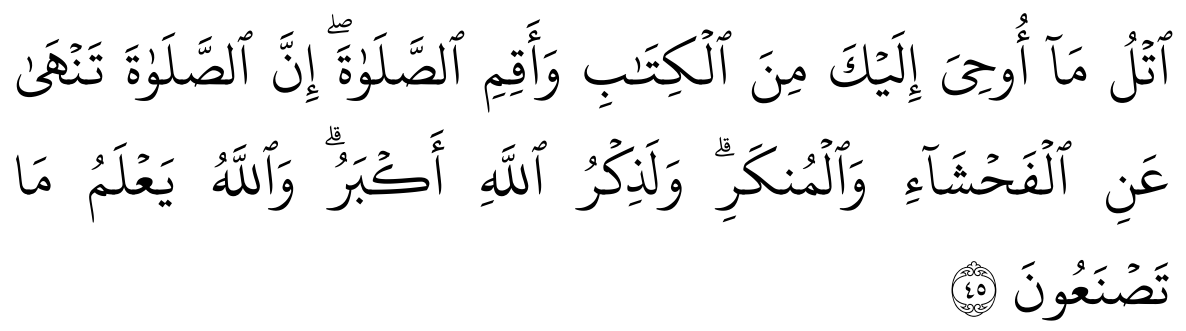

Artinya :"Dan dirikanlah shalat, sesungguhnya itu mencegah dari perbuatan-perbuatan keji dan mungkar”. (QS. Al-Ankabut : 45)

Shalat harus menjadi prioritas utama bagi orang tua kepada anaknya. Shalat merupakan tiang agama, jika seseorang melalaikannya niscaya agama ini tidak bisa tegak pada dirinya. Shalat ini pulalah yang pertama kali akan dihisab oleh Allah di akhirat. Untuk itulah, hendaknya orang tua dengan tiada bosan senantiasa memberikan contoh dengan shalat di awal waktu dengan berjama'ah 
Mahmudin: Tanggung Jawab dan Peran Orang Tua dalam Pendidikan Shalat Bagi Anak Usia Dini

di masjid, mengajaknya serta menanyakan kepada anaknya apakah dia telah menunaikan shalatnya. ${ }^{5}$

Shalat adalah tiang agama. Shalat adalah media untuk membangun hubungan erat dengan Sang Pencipta Allah SWT. Shalat merupakan amalan pertama yang akan dihisab pada hari kiamat. Dan masih begitu banyak keutamaan-keutamaan dari shalat.

Dengan mengetahui betapa pentingnya kedudukan shalat dalam Islam, sudah sewajibnya kita membiasakan anak-anak kita shalat sebagai tujuan dalam pendidikan keimanan anak-anak. Masa anak-anak merupakan masa persiapan, pelatihan dan pembiasaan sampai tiba ketika mereka baligh dimana mereka telah dibebani kewajiban-kewajibannya. Sehingga jika mereka sudah terbiasa shalat semenjak kecil, tentunya akan mudah bagi mereka untuk menunaikan kewajiban-kewajiban agama mereka ketika menginjak masa baligh.

Sebagai kepala rumah tangga haruslah memberikan teladan yang baik dalam mengemban tanggung jawabnya karena Allah 'Azza wa Jalla akan mempertanyakannya di hari Akhir kelak.

Hal ini berdasarkan sabda Rasulullah shallallaahu 'alaihi wa sallam:

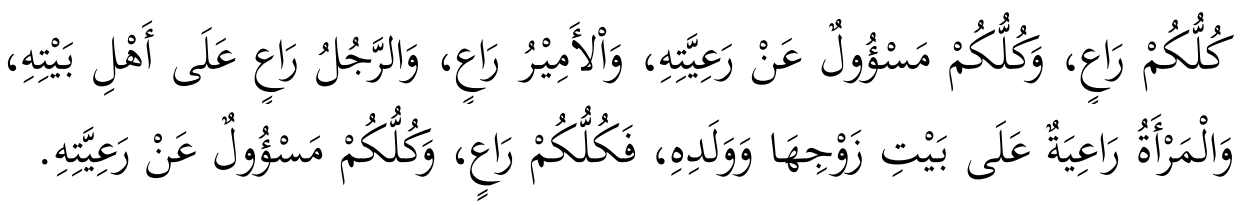

Artinya :"Kamu sekalian adalah pemimpin, dan kamu sekalian bertanggung jawab atas orang yang dipimpinnya. Seorang Amir (raja) adalah pemimpin, seorang suami pun pemimpin atas keluarganya, dan isteri juga pemimpin bagi rumah suaminya dan anak-anaknya. Kamu sekalian adalah pemimpin dan kamu sekalian akan diminta pertanggungjawabannya atas kepemimpinannya ${ }^{6}$.

${ }^{5}$ https://almanhaj.or.id/1048-kewajiban-mendidik-anak.html (11/11/2018, 13:15).

${ }^{6}$ Hadits shahih: Diriwayatkan oleh an-Nasa-i dalam 'Isyratun Nisaa' (no. 292) dan Ibnu Hibban (no. 1562) dari Shahabat Anas bin Malik radhiyallaahu 'anhu. Al- 
Mahmudin: Tanggung Jawab dan Peran Orang Tua dalam Pendidikan Shalat Bagi Anak Usia Dini

Juga sabda beliau shallallaahu 'alaihi wa sallam,

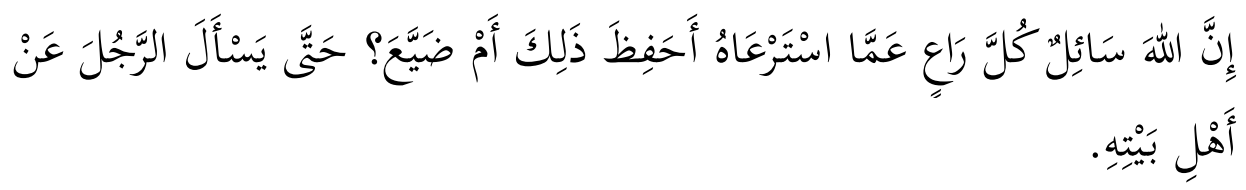

Artinya :"Sesungguhnya Allah akan bertanya kepada setiap pemimpin tentang apa yang dipimpinnya. Apakah ia pelihara ataukah ia sia-siakan, hingga seseorang ditanya tentang keluarganya".

Seorang suami harus berusaha dengan sungguh-sungguh untuk menjadi suami yang shalih, dengan mengkaji ilmu-ilmu agama, memahaminya serta mengamalkan apa-apa yang diperintahkan oleh Allah 'Azza wa Jalla dan RasulNya, serta menjauhkan diri dari setiap yang dilarang oleh Allah 'Azza wa Jalla dan Rasul-Nya. Kemudian dia mengajak dan membimbing sang isteri untuk berbuat demikian juga, sehingga anak-anaknya akan meneladani kedua orang tuanya karena tabiat anak memang cenderung untuk meniru apa-apa yang ada di sekitarnya. ${ }^{8}$

Tanggung jawab akan tumbuh jika anak memiliki dorongan visi yang kuat. Dorongan visi biasanya lahir karena keterkaitan emosi yang dalam juga pemahaman yang cukup terhadap realitas. Keterkaitan emosi lebih mudah tumbuh jika anak menemukan model yang menjadi panutannya. Model adalah figur tempat anak becermin. Jika ia kagum dengan gambaran yang terdapat dalam cermin itu, ia akan memiliki keinginan yang kuat untuk melakukan identifikasi diri. Model ini bisa orang tua, guru, pahlawan, atau tokoh tertentu yang menimbulkan ketakjuban dalam hatinya.

Hafizh Ibnu Hajar menshahihkan hadits ini dalam Fat-hul Baari (XIII/113), lihat Silsilah ash-Shahiihah (no. 1636).

${ }^{7}$ Hadits shahih: Diriwayatkan oleh an-Nasa-i dalam 'Isyratun Nisaa' (no. 292) dan Ibnu Hibban (no. 1562) dari Shahabat Anas bin Malik radhiyallaahu 'anhu. AlHafizh Ibnu Hajar menshahihkan hadits ini dalam Fat-hul Baari (XIII/113), lihat Silsilah ash-Shahiihah (no. 1636).

${ }^{8}$ https://almanhaj.or.id/1048-kewajiban-mendidik-anak.html jam12.00. 
Mahmudin: Tanggung Jawab dan Peran Orang Tua dalam Pendidikan Shalat Bagi Anak Usia Dini

Orang tua adalah pihak yang paling berpeluang untk menjadi model bagi anak-anak mereka. Sebab orang tua adalah figur yang paling dekat dan paling sering dilihat oleh anak. Tumbuhkanlah kekaguman anak kepada orang tua dengan banyak memperlihatkan kebaikan dan keteguhan jiwa dalam memegang prinsip. ${ }^{9}$

Selanjutnya dalam makalah ini akan dijelaskan bagaimana tanggung jawab dan peran orang tua dalam pendidikan shalat bagi anak usia dini.

\section{B. Metodologi Penelitian}

Penelitian ini merupakan riset kepustakaan (Library research), maka penelitian ini dimulai dengan proses penghimpunan bahan dan sumber data dalam bentuk buku, makalah, artikel, dan tulisan yang berkaitan dengan topik penelitian. Selanjutnya, penulis membaca data-data tersebut dan mencatatnya. Sesudah itu, penulis mengkategorikan data dan menyeleksi data-data tersebut untuk identifikasi tentang tanggung jawab dan peran orang tua terhadap pendidikan shalat bagi anak usia dini. Jadi, teknik pengumpulan data melalui dokumen yang terkait dengan topik penelitian. Sumber data yang digunakan dalam penelitian ini adalah karya-karya penulis lain yang berkaitan dengan tema penelitian baik berupa buku, artikel, majalah maupun tulisan lain. Analisis data dalam penelitian ini dilakukan dengan teknik conten analisys yaitu menganalisis data sesuai kandungan isinya. Sedangkan metode analisis datanya menggunakan metode deduktif.

\section{Pembahasan}

1. Pengertian tanggung jawab

Dalam kamus besar bahasa indonesia arti tanggung jawab adalah keadaan wajib menanggung segala sesuatunya (kalau terjadi apa-apa 91,93-94

${ }^{9}$ Abullah Munir, Pendidikan Karakter (Yogyakarta: Pustaka Insani, 2010), h. 90- 
Mahmudin: Tanggung Jawab dan Peran Orang Tua dalam Pendidikan Shalat Bagi Anak Usia Dini

boleh dituntut, dipersalahkan, diperkarakan, dan sebagainya), ${ }^{10}$ Dalam pergaulan sehari-hari bertanggung jawab pada umumnya diartikan sebagai "berani menanggung risiko (akibat) dari suatu perbuatan atau tindakan yang dilakukan”. Atau sering pula diartikan sebagai "berani mengakui suatu perbuatan atau tindakan yang telah dilakukan". Pengertian tanggung jawab tersebut belum cukup, karena yang bersangkutan tidak pernah memikirkan apakah perbuatan atau tindakannya itu sesuai dengan nilai-nilai hidup yang luhur, apakah sesuai dengan nilai-nilai susila yang berlaku dalam kehidupan manusia yang sopan beradab, dan beragama. ${ }^{11}$

2. Ayat-ayat tentang tanggung jawab orang tua terhadap pendidikan anak

Adapun ayat yang menjelaskan tentang tanggung jawab orang tua terhadap pendidikan anak sebagai berikut: Q.S. at-Tahrim ayat 6:

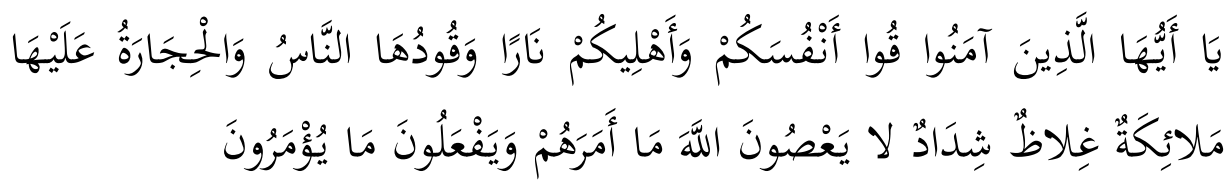

Artinya : "Hai orang-orang yang beriman, peliharalah dirimu dan keluargamu dari api neraka yang bahan bakarnya adalah manusia dan batu; penjaganya malaikat-malaikat yang kasar, keras, dan tidak mendurhakai Allah terhadap apa yang diperintahkan-Nya kepada mereka dan selalu mengerjakan apa yang diperintahkan”.

Dan firman Allah SWT:

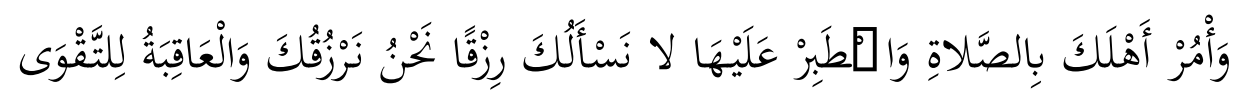

Artinya :"Dan perintahkanlah kepada keluargamu mendirikan shalat dan bersabarlah kamu dalam mengerjakannya. Kami tidak meminta rezeki kepadamu, Kamilah yang memberi rezeki kepadamu. Dan akibat (yang baik) itu adalah bagi orang yang bertakwa”. (Q.S. Thaaha:132).

\footnotetext{
${ }^{10}$ https://kbbi.web.id/tanggung\%20jawab (10 Nopember 2018) jam 20:40.

${ }^{11}$ Uyoh Sadulloh, dkk, Pedagogik, (Bandung: Alfabeta,2010), h.175.
} 
Mahmudin: Tanggung Jawab dan Peran Orang Tua dalam Pendidikan Shalat Bagi Anak Usia Dini

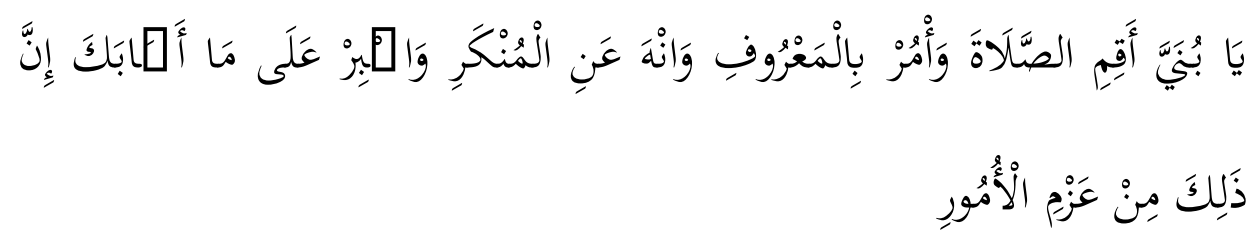

Artinya : "Hai anakku, dirikanlah shalat dan suruhlah (manusia) mengerjakan yang baik dan cegahlah (mereka) dari perbuatan yang mungkar dan bersabarlah terhadap apa yang menimpa kamu. Sesungguhnya yang demikian itu termasuk hal-hal yang diwajibkan (oleh Allah)”. (Q.S. Luqman: 17).

3. Peran orang tua dalam pendidikan anak

Orang tua merupakan pendidik utama dan pertama bagi anak-anak didik, karena dari merekalah anak mula-mula menerima pendidikan. Dengan demikian bentuk pertama dari pendidikan terdapat dalam kehidupan keluarga, lingkungan keluarga merupakan tempat seseorang memulai kehidupannya, keluarga membentuk suatu hubungan yang sangat erat antara ayah, ibu dan anak, hubungan tersebut terjadi karena anggota keluarga saling berinteraksi. Dari lingkungan itulah anak mengalami proses pendidikan dan sosialasi awal.

Berikut ini adalah tanggung jawab pendidikan Islam yang menjadi beban orang tua kepada anaknya sekurang-kurangnya harus dilaksanakan dalam rangka :

a. Memelihara dan membesarkan anak. Ini adalah bentuk yang paling sederhana dari tanggungjawab setiap orang tua dan merupakan dorongan alami untuk mempertahankan kelangsungan hidup manusia.

b. Melindungi dan menjamin kesamaan, baik jasmaniah maupun rohania, dari berbagai gangguan penyakit dan dari penyelewangan kehidupan dari tujuan hidup yang sesuai dengan falsafat hidup dan agama yang di anutnya.

c. Memberi pengajaran dalam arti yang luas sehingga anak memperoleh peluang untuk memiliki pengetahuan dan kecakapan seluas dan setinggi munkin yang dapat dicapainya. 
Mahmudin: Tanggung Jawab dan Peran Orang Tua dalam Pendidikan Shalat Bagi Anak Usia Dini

d. Membahagiakan anak, baik dunia maupun akhirat, sesuai dengan pandangan dan tujuan hidup muslim. ${ }^{12}$

Ajaran islam meletakkan dua alasan utama bagi permasalahan anak, pertama tentang hak dan kedudukan anak, kedua tentang pembinaan sepanjang pertumbuhannya. ${ }^{13}$ Di atas kedua landasan inilah yang merupakan dambaan bagi setiap muslim.

Beberapa peran orang tua dalam mendidik anak antara lain: ${ }^{14}$

a. Terjadinya hubungan yang harmonis dalam keluarga melalui penerapan pola asuh islami sejak dini.

b. Kesabaran dan ketulusan, sikap sabar dan ketulusan hati orang tua dapat mengantarkan anak dalam kesuksesan anak.

c. Orang tua wajib mengusahakan kebahagian bagi anak dan menerima keadaan anak apa adanya, mensyukuri nikmat yang diberikan Allah SWT.

d. Mendisiplinkan anak dengan kasih sayang dan bersikap adil.

e. Komunikatif yang baik.

f. Memahami anak dengan segala aktivitasnya, termasuk pergaulannya.

4. Pendidikan shalat

Secara etimologi pendidikan menurut John Dewey yaitu"Etimologically, the word education means just a process of leading or bringing $u p " .{ }^{15}$ Adapun pengertian pendidikan oleh para pakar antara lain didefinisikan sebagai berikut:

a. Menurut Ahmad tafsir

Pendidikan adalah usaha meningkatkan diri dalam segala aspek. ${ }^{16}$

b. Menurut Ahmad D. Marimba

${ }^{12}$ ZakiahDaradjat, dkk, IlmuPendidikan Islam.cet. 11 (Jakarta.BumiAksara: 2014), h. 35- 38

${ }^{13}$ Samsul munir amin, Menyiapkan Masa Depan Anak Secara Islami (Jakarta: Amzah, 2007), h. 16.

${ }^{14}$ Samsul munir amin, Menyiapkan Masa Depan..h,21-25.

${ }^{15}$ John Dewey, Democracy and Education, (New York: the Mac Millan Company, 1964), h.10.

${ }^{16}$ Ahmad Tafsir, Metodologi Pengajaran Agama Islam, (Bandung: Remaja Rosda Karya, 1997), h. 6. 
Mahmudin: Tanggung Jawab dan Peran Orang Tua dalam Pendidikan Shalat Bagi Anak Usia Dini

Pendidikan adalah bimbingan atau pimpinan secara sadar oleh si pendidik terhadap perkembangan jasmani dan rohani anak didik menuju terbentuknya kepribadian yang utama. ${ }^{17}$

c. Menurut Langeveled

Pendidikan adalah suatu bimbingan yang diberikan orang dewasa kepada anak yang belum dewasa untuk mencapai tujuan yaitu kedewasaan. ${ }^{18}$

Dari beberapa pengertian diatas dapat disimpulkan bahwa pendidikan merupakan usaha membimbing dan membina serta bertanggung jawab untuk mengembangkan intelektual pribadi anak didik ke arah kedewasaan dan dapat menerapkannya dalam kehidupan sehari-hari. Pendidikan lebih mengarahkan tugasnya kepada pembinaan dan pembentukan sikap dan kepribadian manusia yang ruang lingkupnya meliputi pada proses mempengaruhi dan membentuk kemampuan kognitif, afektif dan psikomotor dalam diri manusia. Berbeda dengan pengajaran yang lebih menitikberatkan usahanya kearah terbentuknya kemampuan maksimal intelektual dalam menerima, mamahami, menghayati dan menguasai serta mengembangkan ilmu pengetahuan yang diajarkan. ${ }^{19}$

Adapun yang dimaksud dengan pendidikan shalat adalah cara yang digunakan dalam upaya mendidik anak untuk terbiasa melakukan shalat sejak dini agar kelak terbiasa melakukannya dengan kesadarannya sendiri.

Pendidikan shalat adalah usaha sadar untuk menyiapkan anak usia dini melalui bimbingan orang tua dalam pengajaran, latihan tentang tindakan shalat yang merupakan kewajiban yang harus ditunaikan dan sangat diancam bagi yang meninggalkan.

Pendidikan shalat adalah usaha sadar untuk menyiapkan peserta didik melalui kegiatan bimbingan pengajaran, latihan tentang tindakan shalat yang

\footnotetext{
${ }^{17}$ Ahmad D. Marimba, Pengantar Filsafat Pendidikan Islam (Bandung: AlMa'arif, 1989), h. 19.

${ }^{18}$ Burhanuddin $\quad$ Salam, Pengantar Paedagogig (Dasar-dasar ilmu pengetahuan) (Jakarta: Rineka Cipta, 1997), h. 3-4.

${ }^{19}$ H. M. Arifin, Filsafat Pendidikan Islam (Jakarta: Bumi Aksara, 1993), h. 100.
} 
Mahmudin: Tanggung Jawab dan Peran Orang Tua dalam Pendidikan Shalat Bagi Anak Usia Dini

merupakan kewajiban yang harus ditunaikan dan sangat diancam bagi yang meninggalkan. ${ }^{20}$

Pembinaan ibadah merupakan penyempurna dari pembinaan akidah. Sedangkan pendidikan shalat merupakan cerminan dari akidah.Akidah anak dapat tertanam kuat dalam jiwanya jika disiram dengan air ibadah dalam berbagai bentuk dan macamnya. Masa kanak-kanak bukanlah masa pembebanan kewajiban. Ia adalah masa persiapan, latihan dan pembiasaan untuk menyambut masa pembebanan kewajiban (taklif) ketika ia telah baligh nanti. $^{21}$ Dengan begitu, kelak pelaksanaan kewajiban akan terasa mudah dan ringan. Disamping itu juga sudah mempunyai kesiapan yang matang untuk menyelami kehidupan dengan penuh keyakinan.

Tidak mudah mengajarkan anak-anak untuk mulai bisa menjalankan sholat, ini memerlukan berbagai persiapan seperti bagaimana cara berwudhu, mengajari mereka tentang rukun-rukun sholat, hal-hal yang diwajibkan, disunahkan, serta hal-hal yang membatalkannya. Berikut ini adalah beberapa cara mengajarkan anak-anak untuk sholat, yaitu $:^{22}$

a. Beri teladan: orang tua hendaknya memberikan keteladanan bagi anaknya dalam masalah menjaga shalatnya. Bagi ayah, biasakan untuk shalat di masjid, namun tak ada salahnya sebelum berangkat ke masjid, biasakan untuk berpamitan dengan si kecil. Adapun ibu, ia dapat mencontohkan secara langsung bagaimana shalat dilakukan, yaitu denga cara meletakkan anak tidak jauh dari tempat shalat ibu dengan harapan anak akan melihat setiap gerakan ibunya. Keteladanan orang tua menjadi bekal utama bagi anak dalam meniru setiap tingkah laku orang-orang disekitarnya. Ketika Rasulullah bersama Siti Khadijah mengerjakan shalat, Sayyidina Ali yang

\footnotetext{
${ }^{20}$ Jaudah Muhammad Awwad, Mendidik Anak secara Islami, Terj. Shihabuddin, cet. ke I (Jakarta: Gema Insani Press, 1995), h. 134.

${ }^{21}$ Salafuddin Abu Sayyid, Mendidik Anak Bersama Nabi (Solo: Pustaka Arafah, 2004), h.174.

${ }^{22}$ Asadulloh al-faruq, Mendidik Balita Mengenal Agama (solo: kiswah media, 2010), h.77-78.
} 
Mahmudin: Tanggung Jawab dan Peran Orang Tua dalam Pendidikan Shalat Bagi Anak Usia Dini

masih kecil datang dan menunggu sampai selesai. Kemudian bertanya tentang apa yang sedang dilakukan Rasulullah. Dan Rasulullah menjawab bahwa beliau sedang menyembah Allah. Lalu Ali mengikuti mereka. Hal ini menunjukkan bahwa keteladanan dan kecintaan terhadap anak akan membawa mereka mempercayai pada kebenaran perilaku, sikap dan tindakan. ${ }^{23}$ Pengalaman keagamaan yang menarik bagi anak diantaranya adalah shalat berjama'ah. Anak merasa senang melihat dan berada di dalam tempat ibadah (masjid, mushalla, surau dan sebagainya). Anak-anak umur 2-5 tahun senang melakukan shalat tarawih, walaupun mereka belum mampu duduk atau berdiri lama. Suatu pengalaman keagamaan lain yang tidak mudah terlupakan oleh anak yaitu shalat hari raya, karena mereka berpakaian baru bersama teman-temannya. Anak -anak merasa senang dan bangga mendapat kesempatan bersama orang tua dan anggota keluarga lainnya dalam menjalani kehidupan keagamaan dalam kehidupan seharihari. $^{24}$

b. Ajarkan tata cara shalat.Hal ini dimaksudkan supaya mendidik dengan menggunakan materi pendidikan baik menggunakan alat atau benda, seraya memperagakan dengan harapan menjadi jelas dan gamblang sekaligus dapat mempraktekkan materi yang dimaksud. ${ }^{25}$ Ajarkan anak anda untuk mengenal gerakan shalat-gerakan shalat secara bertahap. Pada awalnya anda bisa mengajarkan bagaimana bertakbir, dan ajaklah si kecil untuk menirukannya. Proses pembelajaran bagi si kecil hendaknya dilakukan dengan suasana rileks dan penuh keseriusan, sehingga anak dapat menikmatinya. Tidak perlu memaksakan, tetapi birkan anak berkembang secara bertahap.

\footnotetext{
${ }^{23}$ Abdul Majid, Perencanaan Pembelajaran Mengembangkan Standar Kompetensi Guru (Bandung: Remaja Rosda Karya, 2005), hlm. 153

${ }^{24}$ Zakiah Daradjat, IlmuPendidikan., h.61.

${ }^{25}$ Abdul Majid, Perencanaan Pembelajaran Mengembangkan Standar Kompetensi Guru (Bandung: Remaja Rosda Karya, 2005), h. 153.
} 
Mahmudin: Tanggung Jawab dan Peran Orang Tua dalam Pendidikan Shalat Bagi Anak Usia Dini

Berkenaan dengan metode praktek dalam perintah shalat, Rasulullah bersabda dalam haditsnya yang artinya: Shalatlah kamu sebagaimana engkau sekalian melihat aku shalat. sesungguhnya memberi pengalaman praktis berarti memberi masukan wawasan dan ilmu pengetahuan. Selain itu juga wawasan anak menjadi luas. Sebagaimana dalam Hadits yang diriwayatkan oleh Bukhari yaitu:

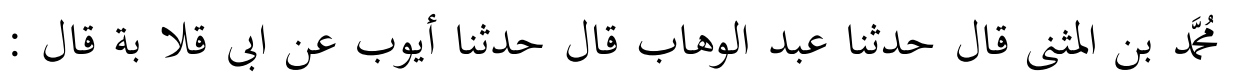

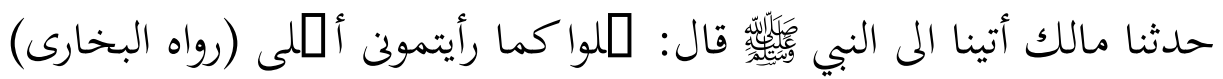
Artinya :"Muhammad bin Mutsanna bercerita kepada kami, berkata:bahwa Abdul Wahab menceritakan kepada kami, berkata:Ayub bin Qilabah bercerita kepada kami, bahwa Malik bercerita kepada kami, bahwa Rasulullah SAW bersabda:"Shalatlah sebagaimana kamu melihat aku shalat (kerjakanlah shalat menurut cara mengerjakannya)" (H.R.Bukhari). ${ }^{26}$

c. Jelaskan mengapa harus shalat. Bisa jadi di dalam diri seorang anak ada sebuah pertanyaan kritis "mengapa harus shalat" karena itu, tidak ada salahnya jika orang tua memberikan penjelasan sederhana mengapa harus shalat. Anda bisa menjelaskan kepada si kecil bahwa shalat adalah perintah Allah. Shalat juga merupakan bentuk rasa syukur kita kepada Allah. Perhatian dan motivasi orang tua kepada anaknya ketika anak dalam usia dini diberi perhatian dan nasehat bagaimana pentingnya sebuah ajaran agama untuk dita'ati dan diberi motivasi agar anak mau melaksanakan perintah agama dengan berbagai bentuk motivasi yang dikehendaki sesuai dengan minat anak tersebut. Sebagaimana firman Allah;

${ }^{26}$ Akhmad Ali bin Hajar al-Asqalani,Fathhul Barii (Sarah Shahih Imam Abi Abdillah Muhammadbin Ismail al Bukhari), Hadits No.631, juz II, (Bairut Libanon:Darul Fikr,t.th.), h. 111. 
Mahmudin: Tanggung Jawab dan Peran Orang Tua dalam Pendidikan Shalat Bagi Anak Usia Dini

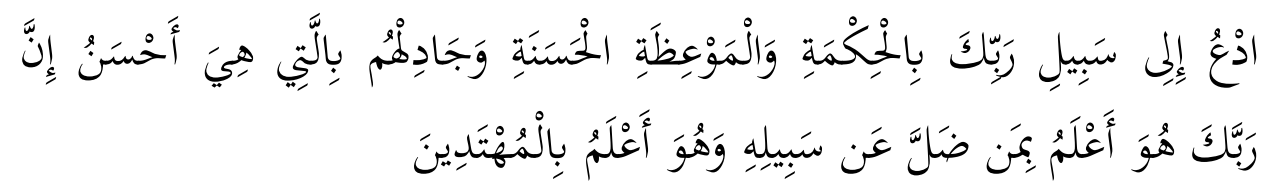

Artinya :"Ajaklah (manusia) kepada jalan Tuhanmu dengan dengan hikmah dan nasehat yang baik.Dan bantahlah mereka dengan (tukar pikiran) yang baik pula.Sesungguhnya Tuhanmu sangat mengetahiu tentang siapa yang tersesat dari jalanNya dan Dialah yang lebih mengetahui siapa orang yang mendapat petunjuk.(An Nahl:125)

d. Penyediaan fasilitas. Fasilitas merupakan sarana dan prasarana pendukung terajadinya proses belajar. Oleh sebab itu motivasi yang tidak kalah pentingnya dalam mengubah pribadi anak adalah kelengkapan fasilitas belajar agama dan memudahkan ia belajar agama dengan begitu kecakapan dalam belajar agama dan beribadah akan terwujud. Salah satunya dengan memberikan perlengkapan shalat dengan motif yang menarik. Namuh demikian, hendaknya tidak memilih motif berupa gambar makhluk bernyawa, seperti manusia atau binatang.

e. Pemberian hadiah dan pujian, hadiah dan pujian merupakan alat motivasi yang dapat menjadikan pedomanbagi anak untuk belajar lebih baik dan giat. Hadiah atau imbalan adalah merupakan suatu cara yang dipakai atau digunakan orang tua dalam mendukung sikap dan tindakan yang baik yang ditunjukkan oleh anak. Hadiah yang dimaksud disini adalah yang berupa barang, barang ini dapat terdiri dari alat-alat keperluan mengaji seperti kopyah, kitab buku pelajaran dan sebagainya.

\section{Simpulan}

Setiap rumah tangga haruslah memiliki keinginan untuk mewujudkan keluarga yang sakinah, mawaddah wa rahmah. Sehingga setiap anggota keluarga harus memiliki peran dan menjalankan amanah tersebut. Sang suami sebagai kepala rumah tangga haruslah memberikan teladan yang baik dalam 
Mahmudin: Tanggung Jawab dan Peran Orang Tua dalam Pendidikan Shalat Bagi Anak Usia Dini

mengemban tanggung jawabnya karena Allah 'Azza wa Jalla akan mempertanyakannya di hari Akhir kelak.

Salah satu kewajiban yang harus dilaksanakan oleh orang tua adalah pendidikan shalat bagi anak usia dini. Hal ini bertujuan agar nantinya dimasa yang akan akan menjadi sebuah kebiasaan bagi anak untuk taat melakukan shalat, kalau saja orang tua melalaikan tanggung jawab ini, maka dia akan berdosa bahkan merupakan dosa besar karena dia menyia-nyiakan amanah yang diberikan Allah kepadanya. 
Mahmudin: Tanggung Jawab dan Peran Orang Tua dalam Pendidikan Shalat Bagi Anak Usia Dini

\section{Daftar Pustaka}

Akhmad Ali bin Hajar al-Asqalani. Fathhul Barii (Sarah Shahih Imam Abi Abdillah Muhammad bin Ismail al Bukhari), Bairut Libanon:Darul Fikr,t.th.

al-faruq, Asadulloh. Mendidik Balita Mengenal Agama, Solo: Kiswah Media, 2010.

al-Halawani, Aba Firdaus. Melahirkan Anak Shaleh, Yogyakarta: Mitra Pustaka, 2003.

Amin, Samsul munir. Menyiapkan Masa Depan Anak Secara Islami Jakarta: Amzah, 2007.

Arifin, H. M. Filsafat Pendidikan Islam, Jakarta: Bumi Aksara, 1993.

Awwad, Jaudah Muhammad. Mendidik Anak secara Islami, Terj. Shihabuddin, cet. ke I, Jakarta: Gema Insani Press, 1995.

Aziz, Amka Abdul. Hati Pusat Pendidikan Karakter, Klaten : Cempaka Putih, 2012.

D. Marimba, Ahmad. Pengantar Filasafat Pendidikan Islam, Bandung: AlMa'arif, 1989.

Daradjat, Zakiah. Ilmu Pendidikan Islam, Cet. I, Jakarta: Bumi Aksara, 1996.

Dewey, John. Democracy and Education, New York: the Mac Millan Company, 1964.

https://almanhaj.or.id/1048-kewajiban-mendidik-anak.html

https://kbbi.web.id/tanggung\%20jawab.

Majid, Abdul. Perencanaan Pembelajaran Mengembangkan Standar Kompetensi Guru, Bandung: Remaja Rosda Karya, 2005.

Munir, Abullah. Pendidikan Karakter, Yogyakarta: Pustaka Insani, 2010.

Sadulloh, Uyoh, dkk. Pedagogik, Bandung: Alfabeta, 2010.

Salam, Burhanuddin. Pengantar Paedagogig (Dasar-dasar ilmu pengetahuan), Jakarta: Rineka Cipta, 1997.

Sayyid, Salafuddin Abu. Mendidik Anak Bersama Nabi, Solo: Pustaka Arafah, 2004.

Setiawan, Agus, Metode Pendidikan Islam Masa Kini dalam Keluarga Perspektif Abdullah Nashih Ulwan, EDUCASIA, Vol. 1 No. 2, 2016. 
Mahmudin: Tanggung Jawab dan Peran Orang Tua dalam Pendidikan Shalat Bagi Anak Usia Dini

Tafsir, Ahmad, Metodologi Pengajaran Agama Islam, Bandung: Remaja Rosda Karya, 1997. 